

\title{
Social Programs and Formal Employment: Evidence from the Brazilian Bolsa Família Program
}

by Anna Fruttero, Alexandre Ribeiro Leichsenring, and Luis Henrique Paiva

IMF Working Papers describe research in progress by the author(s) and are published to elicit comments and to encourage debate. The views expressed in IMF Working Papers are those of the author(s) and do not necessarily represent the views of the IMF, its Executive Board, or IMF management. 


\title{
IMF Working Paper
}

Strategy, Policy and Review Department

\section{Social Programs and Formal Employment: Evidence from the Brazilian Bolsa Família Program}

\section{Prepared by Anna Fruttero, Alexandre Ribeiro Leichsenring, Luis Henrique Paiva ${ }^{1}$}

Authorized for distribution by Johannes Wiegand

June 2020

\section{IMF Working Papers describe research in progress by the author(s) and are published to elicit comments and to encourage debate. The views expressed in IMF Working Papers are those of the author(s) and do not necessarily represent the views of the IMF, its Executive Board, or IMF management.}

\begin{abstract}
Employment is key to combating poverty. Thus, detractors of social assistance programs argue that they create disincentives to work. While there is substantial evidence showing limited effects of these programs on overall labor supply, the jury is still out with respect to their impact on formal employment. This paper exploits an unannounced change in the eligibility rule of the Bolsa Familia program in Brazil, one of the oldest and largest conditional cash transfers in the world, to identify the causal impact of the program on formal employment, combining three large administrative datasets. This paper finds that the program has a positive effect on entry in formal labor market, especially for younger cohorts.
\end{abstract}

JEL Classification Numbers: I38, J22.

Keywords: Anti Poverty, Poverty, Welfare, Well Being, Informality, Social programs, Brazil, Latin America, Labor Market.

Authors’ E-Mail Addresses: afruttero@imf.org, alexandre.leichsenring@usp.br, luis.paiva@ipea.gov.br

\footnotetext{
${ }^{1}$ Fruttero: International Monetary Fund; Leichsenring: State University of Sao Paulo - USP, Brazil; Paiva: Institute for Applied Economic Research - IPEA, Brazil. For helpful comments we thank Stephen Ayerst, Fernanda Brollo, Valentina Flamini, Sergei Soares, Frederik Toscani, and participants of various seminars. The research results and conclusions expressed herein are those of the authors and do not necessarily reflect the views of the IMF or IPEA.
} 
ABSTRACT _ _ 2

I. INTRODUCTION _ 4

II. BENEFICIARY SELECTION AND LINK TO THE FORMAL LABOR MARKET _ 6

III. DATA _ _ 7

IV. BOLSA FAMÍLIA BENEFICIARIES AND FORMAL EMPLOYMENT____ 8

A. Identification Strategy _ 10

B. Results

C. Robustness check

V. CONCLUSIONS _ 18

REFERENCES _ 20

\section{FIGURES}

1. Distribution of working age individuals registered in the Single Registry in

2. Percentage of Newly Eligible in Each State that Entered the Program __ 12

3. Labor market formalization of Bolsa Familia beneficiaries and Non Bolsa Familia __ 15

\section{TABLES}

1. Number of families entering and exiting Bolsa Familia Program (2004-2011).

2. Profile of working age individuals registered in the Single Registry on December__ 9

3. Growth formal employment by age-group and participation in Bolsa Familia $\_10$

4. Entry in Bolsa Familia after Change in Eligibility Rule in July 2007

5. Matching - balancing of observable across treatment and control groups __ 13

6. Probability of being formal for all sample and by gender

7. Probabilities of being formal by age group __ 16

8. Simple DID estimator

9. DID estimator using propensity score matching ___ 18 


\section{NTRODUCTION}

Cash transfer programs emerged in the mid-1990s in Latin America as anti-poverty programs and have become a prominent element of social protection systems in many middle and lowincome countries, having been implemented in almost 70 low- and middle-income countries (World Bank 2017). Through redistribution of resources, they aim at alleviating poverty, supporting households manage risk, and break the intergenerational cycle of poverty by fostering households' investment in the human capital of their children. Currently, as the Covid-19 is creating an unprecedented economic crisis, many governments are resorting to social protection programs like cash transfer programs to sustain livelihoods.

With poverty around the world associated with limited access to good job opportunities, government programs should aim at fostering employment and employability. Thus, critics of cash transfer programs argue that they create dependency and that, while providing essential support to families in need, they hinder sustainable poverty reduction. The concern is that these programs create negative dependence, that is "current needs are met at the cost of reducing beneficiaries' ability to meet their basic needs in the future without external assistance" (Lentz et al., 2005). This reduced ability of beneficiaries to meet future needs results from the disincentive to work generated by income transfers.

Theoretically transfers reduce labor supply through an income effect and a high tax rate on marginal earnings (Kanbur et al., 1994; Borjas, 2005). The larger the transfers and the larger the marginal tax rate on earnings, the larger the reduction of labor supply is expected to be (Moffit 2002; Borjas 2005). Adjusting the benefit design in order to avoid possible negative effects on labor supply is not simple. While social benefits could be paid to the working poor - which is the case of tax credits - the overall impact remains ambiguous: tax credits should encourage the non-working poor to work but could have a negative impact on near-poor, higher-labor-supply individuals (Moffitt 2002). The adoption of time limits could also increase labor supply, but at a risk of leaving the virtually unemployable poor without any social protection (Duncan, Harris and Boisjoly 2000). Finally, work requirements (which should have an unambiguous positive effect on labor supply) face tremendous difficulties: differentiating those who can work from those who cannot can be operationally complicated, expensive and give excessive discretion to the street-level bureaucracy (Moffit 2002).

But the transfers could also have a positive effect on labor supply. In a situation of liquidity and credit constraints, the presence of modest but relatively stable social benefits could be useful for beneficiaries to meet the costs of job searching and encourage them to look for better jobs. Hence, the result could be an increase in labor supply and a change from less desirable to more desirable forms of employment.

In low- and middle-income countries, with a large informal sector, high marginal tax rates on the benefits might not generate a negative impact on labor supply overall but could decrease participation in the formal labor market. Income from informal work, which is very hard to detect by authorities, would avoid the high marginal tax rates of benefits on earnings. Consequently, if earnings in formal and informal jobs are similar, it could be rational for beneficiaries to opt for an informal job, which would allow them to keep receiving their benefits. 
So far, the empirical findings seem to confirm theoretical expectations. Modest cash transfers are not associated with any strong reduction in labor supply. Kabeer and Waddington (2015) find that only one out of eight reviewed studies finds negative impacts on labor force participation (a reduction for mothers in Pakistan), although in other countries (such as in Uruguay and Brazil) reductions in labor supply at the intensive margin can be observed. However, they also identify opposite effects. Adult beneficiaries were more likely to be looking for work in Brazil and Chile, while a transition from unpaid to paid work has been observed in Mexico. Bastagli et al. (2016) reach similar conclusions: three out of eight reviewed studies point to an increase in labor force participation, with one pointing to a reduction. Three of eleven studies reporting on effects at the intensive margin find negative effects. The same lack of effects was observed in the meta-analysis of seven randomized controlled trials (RCTs) of cash transfers performed by Banerjee et al. (2017). Looking for effects both at the extensive and intensive margins, the authors conclude that "This paper does not observe a significant effect of belonging to a transfer program on employment or hours of work in any of the seven programs".

The available evidence for the Bolsa Familia Program (BFP) goes along the same way. Oliveira and Soares (2012) review several studies about the possible impacts of the BFP on labor supply (either on labor force participation or on hours worked). Five out of eight studies suggest a positive effect (but of small magnitude, as expected) on participation, against only one pointing to a negative impact. A small decrease in hours worked is observed in three out of five studies, in general for women. The overall conclusion was that "there is no clear evidence that CCTs strongly discourage labor supply". The study by de Brauw et al (2015), based on data from the two-round impact evaluation of the Bolsa Familia Program, also concludes that there was "no aggregate effects on labor market participation" and "no effect on total household work hours." Thus, the existing evidence suggests that modest transfers do not have a relevant impact on labor supply, though they might decrease marginally the number of hours worked for women.

There could however be a negative effect of Bolsa Familia on formal employment. This possible disincentive to formal employment would be related to eligibility. Most conditional cash transfer (CCT) programs use some form of proxy-means test to determine household eligibility; thus, income is not a direct determinant of eligibility. Bolsa Familia is different: household self-declared income, cross-checked with information from various administrative records, determines eligibility. While wages from formal labor jobs are easily detectable, wages from informal jobs can be hidden as there is no reporting mechanisms nor database containing them. While formal jobs tend to pay more than informal ones, and the cash transfer is not very high, the program ensures a constant stream of income whose predictability is very valuable to households. ${ }^{2}$ For families in or near poverty facing instability in the labor market, a small but predictable transfer can be valuable and worth maintaining despite being offered a formal, but potentially unstable, job.

Formal jobs are protected by a much more robust form of social protection than cash transfer and tend to pay higher wages than informal ones. Barros, Franco and Mendonça (2007)

\footnotetext{
2 Indeed, the introduction of the "retorno garantido" (guaranteed return) in 2012 that ensure a right to reinsertion in the program to families who had willingly left the program to accept a job offer was an acknowledgement of this.
} 
estimated that "workers in the informal sector and the self-employed receive 40 percent lower wages than formal workers with the same productive characteristics, working in the same economic sectors". Thus, choosing to remain in the informal sector could be detrimental in the long term, despite being perceived as more secure in the short-term by beneficiaries.

These different theoretical expectations have been empirically disputed in the Brazilian context. Consistently with the first hypothesis, de Brauw et al (2015) pointed to a "shift of household work hours into the informal sector from the formal sector". This shift towards informality could be caused by the desire of beneficiaries to remain in the program for long periods. But other two other studies seem to be more compatible with the second hypothesis. Based on data from the National Household Survey (Pesquisa Nacional de Amostra por Domicílios - PNAD), Barbosa and Corseuil (2014) find that "the program has no impact on the occupational choice of beneficiaries between formal and informal jobs". Santos et al. (2016), based on combined administrative records from the Bolsa Familia Program and from the formal labor market in Brazil, conclude that the probability of leaving a formal job is between 7 and 10 percent lower for beneficiaries, which compensates the greater probability of leaving the job caused by the presence of small children in the household.

This paper takes an advantage of an unannounced change in the eligibility cutoff and of the existence of rationing of entry into the program at the municipal level due to budget limitation, to estimate the causal impact of the Bolsa Familia conditional cash transfer program on formal employment.

Our analysis finds that participation in Bolsa Familia had a positive effect on formal employment. This effect is differentiated across age groups, with a stronger effect for younger beneficiaries. This finding seems compatible with more sophisticated models of labor supply (such as those that incorporate the costs of looking for a job, as well as credit and liquidity constraints - see Baird, McKenzie and Özler 2018), with the literature on decision-making under scarcity (Mullainathan and Shafir 2013) and with evidence pointing to long-term positive effects of CCTs on labor market outcomes (Barham, Macours and Maluccio 2018).

The paper is organized as follows. Section 2 details how Bolsa Familia beneficiaries are selected. Section 3 presents the databases that will be used in later sections. Section 4 assesses the performance of program beneficiaries in the formal labor market vis-a-vis nonbeneficiaries. Section 5 and Section 6 contain the discussion and conclusions of the paper.

\section{BENEFICIARY SELECTION AND LINK TO THE FORMAL LABOR MARKET}

Bolsa Família is one of the oldest and largest CCT programs in the world. The Ministry of Citizenship (previously named Ministry of Social Development - MDS) is responsible for the program, defines the eligibility criteria and authorizes payments to families. In 2018 over a fifth of Brazil's population was beneficiary of the program, which had a budget of about BRL 30 billion (equivalent to 0.4 percent of GDP). To become beneficiary, a household must be registered in the Single Registry for Social Programs ${ }^{3}$ (Single Registry, from now on). The eligibility criterion is per capita household income (the sum of all incomes of all members of

\footnotetext{
${ }^{3}$ Cadastro Unico para Programas Sociais, or CadUnico.
} 
the household divided by the number of members), as declared in the Single Registry. Bolsa Família is a program targeted to families living in poverty or extreme poverty. An estimate of the number of families living in these situations was established for each municipality, based on data from the Demographic Census, conducted by the Brazilian Institute for Geography and Statistics (IBGE) (Hellman 2015). Thus, the number of families that can enter the program at the municipal level is affected by this estimation (a municipal "quota"). Once the quota is reached, it becomes more difficult for benefits to be granted.

During the registration in the Single Registry, a family member (in general, a woman aged 16 or more) provides detailed information on household composition and the sources of incomes of all family members. Beneficiary families must update their information in the Single Registry whenever a relevant change occurs (e.g. change of address, household composition, or income sources) or at least once every two years. The self-declared income undergoes a process of cross-checks with other national-level administrative records. One of them is the registry of formal employees, the Annual Social Information Report (RAIS). Thus, any income from a job registered in RAIS would be used to determine eligibility. Income from informal work is virtually impossible to detect.

\section{DATA}

The analysis is based on three large administrative records of the Brazilian Federal Government: Single Registry; Historical Database of Benefits of the Bolsa Família Program; and the RAIS.

The Single Registry is used by about 30 social programs of the Brazilian Federal Government. It contains information on more than 25 million low-income families (about 70 million people, a third of the population of the country), including individual (gender, age, race, schooling, labor market status, income, etc.) and household (construction material, access to water services, sanitation, electricity and garbage collection, expenses, etc.) level information. The data is collected by the local governments in the 5,570 Brazilian municipalities, in an online system maintained by the central Government, through a public bank (Caixa Economica). It covers nearly the totality of the country's poorest population. Families receiving benefits from a federal social program are required to update their information every two years. This paper uses a version of the complete dataset extracted in December 2008 containing approximately 70 million individual registers to get 34.3 million people of working age - here defined as those aged between 18 and 65 (men) or 60 (women).

The Historical Database of Benefits of Bolsa Família has been constructed by the authors through intensive computational processing. Starting from the monthly payment sheets of the program, this paper creates a history of entry into and exit from the program for each family since the start of the program. A total of 96 monthly payrolls from January 2004 to December 2011 were concatenated under a computational routine in $\mathrm{R}$ (The R Project for Statistical Computing). Over the period under consideration, the number of families in the program increased from 5.9 to 12.3 million, making a total of 19.8 million families who entered the program at some point (7.43 million of which had left it by the end of the period). The Historical Database of Benefits is composed of this wide universe of beneficiaries, for which 
this paper has, among other information, the exact date of entry and (eventual) exit of the program since its very beginning.

Table 1 - Number of families entering and exiting Bolsa Familia Program (2004-2011).

\begin{tabular}{ccc}
\hline & Entry & Exit \\
\hline 2004 & $6,003,602$ & 78,573 \\
2005 & $2,135,331$ & 219,642 \\
2006 & $3,480,427$ & $1,028,380$ \\
2007 & $1,180,200$ & 937,245 \\
2008 & 940,455 & $1,333,643$ \\
2009 & $2,543,647$ & $1,849,878$ \\
2010 & $1,759,186$ & $1,145,725$ \\
2011 & $1,719,744$ & 839,958 \\
\hline Total & $19,762,592$ & $7,433,044$ \\
\hline
\end{tabular}

Sources: Authors' calculation, based on the Single Registry and the Historical Database of Benefits.

The RAIS is the most comprehensive administrative record on formal employment in Brazil. It covers both public and private sectors throughout the country. Information is provided by employers. In December 2011, RAIS reported 46.3 million formal employment relations. This paper uses six annual versions from 2006 to 2011.

The three datasets were merged using the unique identifier "social identification number" contained in all of them. More detailed information on the resulting dataset is given on the next section.

\section{BOLSA FAMÍLIA BENEFICIARIES AND FORMAL EMPLOYMENT}

In December 2008, amongst individuals registered in the Single Registry, 34.3 million were of working age - here defined as those aged between 18 and 65 (men) or 60 (women). Almost half of them were in the North East Region and were in households with a couple and kids (Figure 1). The number of individuals in the Single Registry with a formal job increased by 1.8 million between 2006 and 2011, from 4.17 million to almost 6 .

Figure 1: Distribution of working age individuals registered in the Single Registry in December 2008, by region, and type of household.
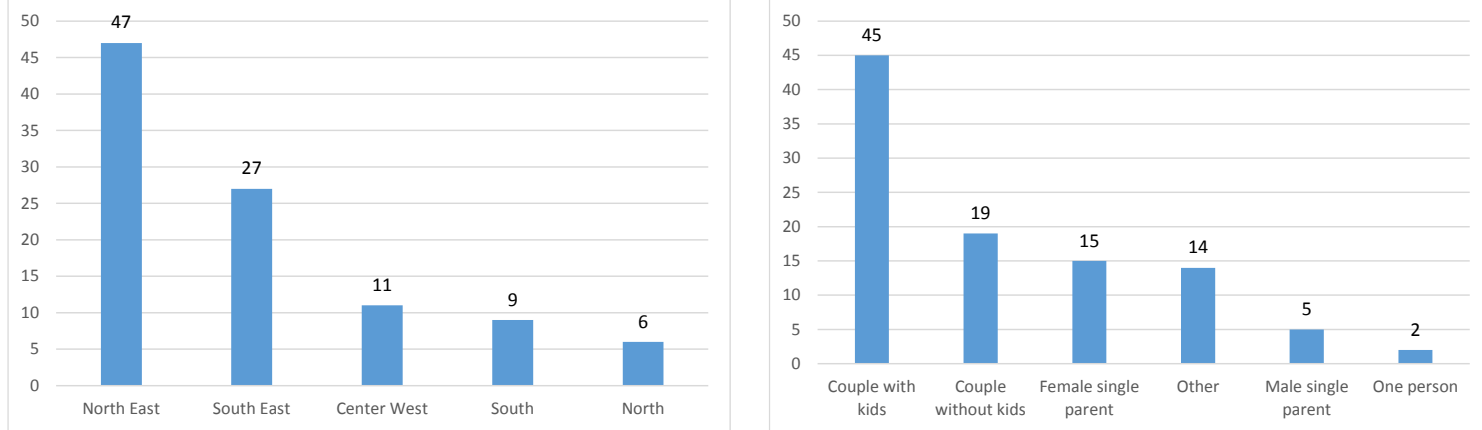

Note: Figures show the percentage of individuals in each group

Source: Authors' calculation, based on the Single Registry for Social Programs - December 2008 
As our objective is to understand the role of Bolsa Familia, this paper devided working aged individuals in the Single Registry into four groups, depending on their receipts of benefits in 2006 and 2011. 35 percent were beneficiaries of the program both in 2006 and in 2011 (the BB group); 21 percent were beneficiaries in 2006 but not in 2011 (BN); 16 percent were not beneficiaries in 2006 but were beneficiaries in 2011 (NB); and 28 percent were not beneficiaries in 2006 nor in 2011 (NN) (see Figure 2 panel b). It is important to remember that households registered in the Single Registry, while not all necessarily poor, are from the most vulnerable segments of the distribution.

Individuals who were beneficiaries in both years had a more vulnerable profile than the others (Table 2). A higher proportion was residing in the North and Northeast Regions (the poorest in the country) and in rural areas; was living in families with children under the age of 16 (or in families with children, regardless of age); had lower education levels; and was in singleparent families.

Table 2 - Profile of working age individuals registered in the Single Registry on December 2008, by participation in Bolsa Familia and characteristics of the household.

\begin{tabular}{|c|c|c|c|c|c|c|c|}
\hline & $\begin{array}{l}\text { Number working } \\
\text { age individuals }\end{array}$ & $\begin{array}{c}\text { Living in North } \\
\text { \& NE }\end{array}$ & Rural & $\begin{array}{l}\text { W/kids } \\
<16 \text { yo }\end{array}$ & $\begin{array}{c}\text { Female } \\
\text { HH }\end{array}$ & $\begin{array}{c}\text { Primary } \\
\text { schooling }\end{array}$ & Black \\
\hline BB & $11,972,421$ & 70.2 & 39.1 & 79.6 & 58.4 & 49.6 & 74.7 \\
\hline $\mathbf{B N}$ & $7,295,443$ & 45.6 & 26.8 & 64.2 & 56.8 & 38.7 & 65.1 \\
\hline NB & $5,503,518$ & 58.9 & 30.9 & 71.7 & 61.7 & 38.0 & 73.1 \\
\hline $\mathbf{N N}$ & $9,555,750$ & 43.5 & 27.0 & 48.4 & 56.1 & 36.9 & 65.8 \\
\hline
\end{tabular}

Sources: Authors' calculation, based on the Single Registry and the Historical Database of Benefits.

The greater vulnerability of the individuals who were beneficiaries of Bolsa Familia in both periods, especially in relation to those who never were, can also be seen from the dynamic of their participation in the labor market over the period 2006-2011. Three quarters of working age individuals in the Single Registry, about 26 million people, never worked in the formal sector between 2006 and 2011. Over 80 percent of individuals who were in the program in both years (BB) had no formal employment at any point over the six-year period analyzed, compared to 73 percent of those who were never in the program (NN). In the BB group, only 5 percent had a continuous presence in formal employment, against 12 percent of the NN group. However, growth in the formal labor market participation was much higher for individuals who were in the program (68 percent) than for those who were not (30 percent) (Figure 2, Panel a).

Registration in the Single Registry is a sign of households' vulnerability. Adults in BFP beneficiary households have low schooling (Camargo et al., 2013) and thus a reduced capacity to take advantage of formal employment. However, through its conditionalities ${ }^{4}$, the program

\footnotetext{
${ }^{4}$ Beneficiaries must comply with education and health requirements. They children need to be enrolled in school and have a minimum attendance rate of 85 percent for children aged 6-15 years or 75 percent for adolescents aged 16 and 17 years. Children under 7 years of age need to have regular vaccination and nutritional (weight and height) monitoring. Pregnant women need to go to prenatal exams. Beneficiary families also need to update their information in the Single Registry whenever a relevant change occurs, such as a change of address,
} 
aims at increasing schooling for the children in these households, and thus should increase their opportunities to access formal employment and contribute to breaking the intergenerational cycle of poverty. It can be harder for older workers to find employment in the formal sector. Indeed, this paper finds that between 2006 and 2011, there is an increase in participation in the formal labor market for all age groups but for those older than 50, with a considerably higher increase for the youngest. Those aged 18 and 19 at the end of 2006 saw an increase in formal labor market participation of 213 percent. The rate of growth decreases as the age increases: for those aged 40 to 50 it increased by only 11 percent and for those higher than 50 it decreased by 17 percent. The largest increase is seen among those that were beneficiary of Bolsa Familia in both years, with the 18 and 19 years old seeing an almost fourfold increase (Table 3).

Table 3 - Growth formal employment by age-group and participation in Bolsa Familia

\begin{tabular}{rccccc}
\hline & Total & BB & NB & BN & NN \\
\hline$[\mathbf{1 8 , 2 0 )}$ & $213 \%$ & $373 \%$ & $181 \%$ & $288 \%$ & $165 \%$ \\
{$[\mathbf{2 0 , 3 0 )}$} & $59 \%$ & $96 \%$ & $48 \%$ & $68 \%$ & $40 \%$ \\
{$[\mathbf{3 0 , 4 0 )}$} & $26 \%$ & $44 \%$ & $20 \%$ & $30 \%$ & $15 \%$ \\
{$[\mathbf{4 0 , 5 0 )}$} & $11 \%$ & $21 \%$ & $9 \%$ & $14 \%$ & $5 \%$ \\
$\mathbf{5 0 +}$ & $-17 \%$ & $-11 \%$ & $-15 \%$ & $-16 \%$ & $-20 \%$
\end{tabular}

Note: $\mathrm{BB}$ refers to individuals in household who were beneficiaries in both year, NB to those who were not and then entered the program, $\mathrm{BN}$ those who were beneficiaries and then no, NN those who were not beneficiary in either year. Sources: Authors' calculations, based on the Single Registry for Social Programs - December 2008, the Historical Database of Benefits (several years) and RAIS (several years).

The evidence so far has shown two important points: (i) the increase in formal labor market jobs between 2006 and 2011 has been higher for beneficiaries of Bolsa Familia than for nonbeneficiaries; and (ii) the growth of formal labor market participation among program beneficiaries was higher for the younger age groups, a desirable outcome. In the next section, this paper investigates the causal effect of Bolsa Familia on this increase in formal labor market participation, by taking advantage of an unexpected change in the threshold to enter the program.

\section{A. Identification Strategy}

The challenge in assessing the causal impact of a program is that this paper cannot observe the counterfactual -what would have happened in the absence of the program. Let $D$ be a dummy variable indicating whether the individual received Bolsa Familia $(D=1)$ or not $(D=0)$. This paper can express outcome $Y$ (i.e. participation in the formal labor market) for individual $i$ as

$$
Y_{i}=Y_{i}^{1} \cdot D_{i}+Y_{i}^{0} \cdot\left(1-D_{i}\right)
$$

where $Y_{i}^{1}$ represents the outcome if she benefits from the program, $Y_{i}^{0}$ if she does not. For every individual this paper can only observe one of the two $-Y_{i}^{1}$ if she benefits from the

household composition, or income sources. Even if no relevant change happens, beneficiary must update critical data, such as income, every two years. 
program, $Y_{i}^{0}$ if she does not, thus this paper cannot calculate the treatment effect, $\left(Y_{i}^{1}-Y_{i}^{0}\right)$. The challenge is to find a credible estimate for the second term, a good approximation of what would have been the outcome for individual $i$ without the program. The evaluation literature has focused on the difference between average outcomes for treated and non-treated, the average treatment effect on the treated (ATT) that is:

$$
A T T=E\left(Y^{1} \mid D=1\right)-E\left(Y^{0} \mid D=1\right)
$$

For this to be a valid comparison, participants and non-participants must have similar characteristics, i.e. they should be comparable a priori, had the treatment not been implemented. If participants and non-participants differ in crucial characteristics that are related both with the participation status and the outcome $\left(E\left(Y^{0} \mid D=1\right) \neq E\left(Y^{0} \mid D=0\right)\right)$, the difference in means between the two groups would have a "selection bias".

To overcome this problem, in situations in which eligibility is based on the household being below (or above) a specific threshold, researchers often use the regression discontinuity approach, in which the counterfactual is represented by those just above (or below) the threshold. However, in the case of Bolsa Familia, there is evidence of manipulation around the eligibility cutoff, with this manipulation consistent with economic incentives of beneficiaries (Silva et al. 2016, Firpo et al. 2014, Camacho and Conover 2011). Thus, this paper cannot use a regression discontinuity design, comparing labor market outcomes of program participants just above and just below the eligibility cutoff.

However, this paper can exploits an unannounced change in the eligibility criterion of the program and the presence of, de facto, municipal quotas for entry into the program to create a control group that allows us to identify the impact of the program on formal labor force participation. In July 2007 the income eligibility cutoff was raised from the original BRL100 per capita to BRL120. Almost 73 thousand families previously ineligible became eligible 5 However, only a third of them became beneficiaries since entry in the program depends on the budget allocation of the Central Government, and the level of coverage of the Program in the municipality where the family is enrolled (Table 4).

Our identification strategy relies on the assumption that entry in the program for the new eligible is not based on specific individual characteristics that takes them apart from those who did not enter the program, nor is affected by households' strategic behavior (since the change in threshold was not announced and this paper considers only families that had updated their information in the Cadastro before the announcement). Rather, entry is determined by municipal quotas and budget allocations that are exogenous to the households ${ }^{6}$.

\footnotetext{
${ }^{5}$ Household with a self-declared income above R \$120 that entered the program (3 percent) are excluded from our analysis.

${ }^{6}$ Priority in funds allocation is given to municipalities with lower coverage rates, to improve the focus of the Program (Barros et al., 2010). We find a negative correlation between entry into the program and the level of quota reached.
} 
Our treatment group are those households that became eligible and entered the program, while the control group are those households that became eligible but did not get into the program. This paper restricts the analysis to families that updated their information before the announcement of the new eligibility criteria, and hence could not have manipulated their selfdeclared income strategically. Consequently, our estimates are of local average treatment effects (LATE).

Table 4: Entry in Bolsa Familia after Change in Eligibility Rule in July 2007

\begin{tabular}{cccc}
\hline & No BFP & BFP & Total \\
\hline $\mathbf{( 1 0 0 , 1 2 0 ]}$ & 49,148 & 23,633 & 72,781 \\
$\mathbf{( 1 2 0 , 1 3 7 ]}$ & 40,183 & 1,429 & 41,612 \\
\hline Total & 89,331 & 25,062 & 114,393 \\
\hline
\end{tabular}

Source: own calculations, based on the Historical

Database of Benefits.

The share of newly eligible households that became beneficiaries varies widely across Brazil. Only 1.3 percent of those eligible became beneficiaries in the Federal District, while almost half (48.7 percent) of those eligible became beneficiaries in the state of Goiás (Figure 2).

Figure 2: Percentage of Newly Eligible in Each State that Entered the Program

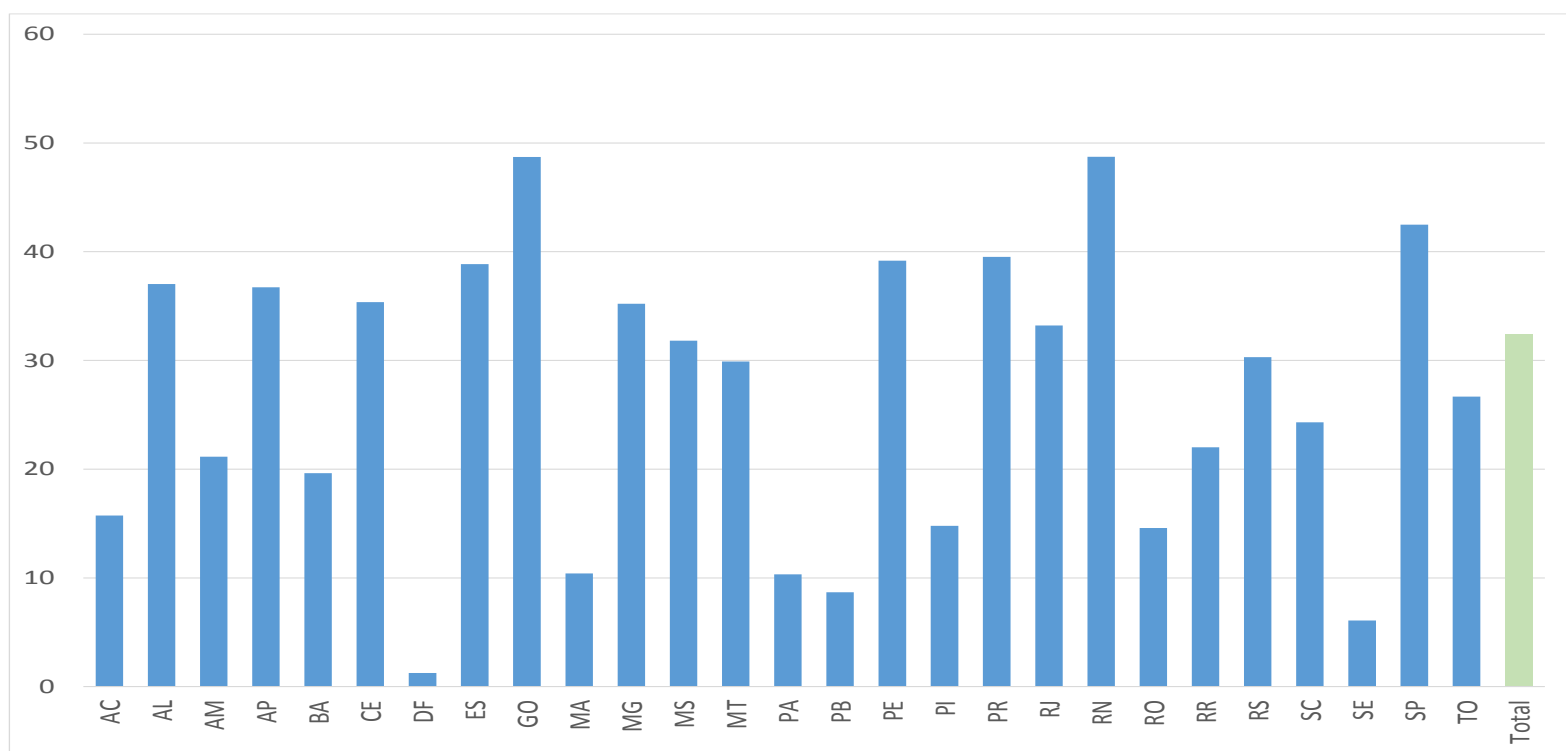

Note: the bars represent the percentage of newly eligible in each state that became beneficiaries Source: own calculation, based on the Historical Database of Benefits.

As this research is interested in entry into the formal labor market, the main concern with respect to our identification strategy is that the quotas and the ease of entry into the program are related to the dynamisms of the economy, and hence to the labor market. For example, if the quotas were all filled in municipalities with a less dynamic labor market, the new beneficiaries would more likely be from more dynamic ones, where it might be easier to find a formal sector job. Thus, the expansion of the programs after the change in the income threshold would be higher in areas that are more likely to experience growth in formal labor market. As a check on our identification strategy, this paper tested for correlation between the 
level of the quotas and growth in formal sector employment at the municipal level. This paper finds no evidence that this is the case ${ }^{7}$.

To account for possible differences in the covariates between the treatment and the control group, this paper estimates the average treatment effect using propensity score matching. Matching is intended to balance the distribution of covariables in the treated and control groups in the evaluation of non-experimental intervention, to reduce bias in the estimation of the treatment effect. This paper uses matching with kernel weights. A weighted composite of comparison observations is used to create a weight for each treated individual, where comparison individuals are weighted by their distance in propensity score from treated individuals within a range, or bandwidth, of the propensity score. Only one observation was outside the common support and was discarded. Table 5 presents the set of observables on which the matching is performed and the results of the test of balancing between the treatment and control groups. The t-tests cannot reject the null hypothesis of equal means, and chisquared test cannot reject the null hypothesis of overall balance as well.

Table 5: Matching - balancing of observable across treatment and control groups

\begin{tabular}{|c|c|c|c|c|c|}
\hline \multirow[b]{2}{*}{ Variables } & \multirow{2}{*}{$\begin{array}{c}\text { Mean } \\
\text { Treatment }\end{array}$} & \multirow{2}{*}{$\begin{array}{c}\text { Mean } \\
\text { Control } \\
\end{array}$} & \multirow[b]{2}{*}{$\%$ bias } & \multicolumn{2}{|c|}{ t-test } \\
\hline & & & & $t$ & $p>|t|$ \\
\hline \multicolumn{6}{|l|}{ Sociodemographics (dummies) } \\
\hline Age $<25$ & 0.218 & 0.213 & 1.1 & 0.94 & 0.35 \\
\hline Age 25-34 & 0.420 & 0.422 & -0.5 & -0.42 & 0.67 \\
\hline Age $35-44$ & 0.256 & 0.257 & 0 & -0.03 & 0.97 \\
\hline Age $45-54$ & 0.089 & 0.091 & -0.4 & -0.36 & 0.72 \\
\hline Age 55-64 & 0.017 & 0.017 & -0.4 & -0.45 & 0.65 \\
\hline Illiterate & 0.039 & 0.041 & -0.9 & -0.91 & 0.36 \\
\hline Some elementary school & 0.163 & 0.164 & -0.2 & -0.18 & 0.85 \\
\hline Completed elementary school & 0.093 & 0.093 & 0 & -0.02 & 0.98 \\
\hline Some middle school & 0.297 & 0.297 & 0.1 & 0.11 & 0.92 \\
\hline Completed middle school & 0.064 & 0.064 & 0 & -0.03 & 0.98 \\
\hline Some High School & 0.123 & 0.122 & 0.5 & 0.43 & 0.66 \\
\hline Completed high school & 0.211 & 0.210 & 0.3 & 0.21 & 0.83 \\
\hline Some graduate school & 0.010 & 0.010 & -0.2 & -0.18 & 0.86 \\
\hline Afro-indigenous & 0.526 & 0.522 & 0.6 & 0.54 & 0.59 \\
\hline Living in urban area & 0.885 & 0.883 & 0.5 & 0.48 & 0.63 \\
\hline Owns house & 0.449 & 0.451 & -0.2 & -0.18 & 0.86 \\
\hline Precarious sanitary drainage & 0.250 & 0.251 & -0.2 & -0.2 & 0.84 \\
\hline Brick house & 0.875 & 0.872 & 0.9 & 0.84 & 0.40 \\
\hline \multicolumn{6}{|l|}{ State of residence: } \\
\hline Acre & 0.001 & 0.001 & -0.3 & -0.3 & 0.76 \\
\hline Alagoas & 0.009 & 0.008 & 0.8 & 0.69 & 0.49 \\
\hline Amazonas & 0.003 & 0.003 & 0 & 0.02 & 0.98 \\
\hline
\end{tabular}

\footnotetext{
${ }^{7}$ The correlation is between -0.02 in 2010-2011 and 0.02 in 2008-2009
} 


\begin{tabular}{|c|c|c|c|c|c|}
\hline Amapa' & 0.004 & 0.004 & -0.3 & -0.23 & 0.82 \\
\hline Bahia & 0.033 & 0.034 & -0.5 & -0.53 & 0.60 \\
\hline Ceara' & 0.056 & 0.056 & 0 & 0 & 1.00 \\
\hline Distrito Federal & 0.002 & 0.003 & -0.6 & -1.89 & 0.06 \\
\hline Espiritu Santo & 0.024 & 0.024 & 0 & 0.01 & 0.99 \\
\hline Goias & 0.059 & 0.058 & 0.6 & 0.44 & 0.66 \\
\hline Maranhao & 0.004 & 0.005 & -0.2 & -0.34 & 0.73 \\
\hline Minas Gerais & 0.186 & 0.186 & -0.1 & -0.12 & 0.91 \\
\hline Mato Grosso do Sul & 0.009 & 0.010 & -0.3 & -0.28 & 0.78 \\
\hline Mato Grosso & 0.015 & 0.015 & -0.1 & -0.12 & 0.90 \\
\hline Para' & 0.006 & 0.006 & -0.3 & -0.39 & 0.70 \\
\hline Paraiba & 0.005 & 0.005 & -0.1 & -0.19 & 0.85 \\
\hline Pernambuco & 0.049 & 0.048 & 0.4 & 0.29 & 0.77 \\
\hline Piaui' & 0.006 & 0.006 & -0.2 & -0.29 & 0.77 \\
\hline Parana & 0.100 & 0.100 & 0.1 & 0.07 & 0.95 \\
\hline Rio de Janeiro & 0.061 & 0.059 & 0.6 & 0.54 & 0.59 \\
\hline Rio Grande do Norte & 0.050 & 0.046 & 1.8 & 1.36 & 0.18 \\
\hline Roraima & 0.003 & 0.003 & -0.2 & -0.27 & 0.78 \\
\hline Rondonia & 0.001 & 0.002 & -0.5 & -0.45 & 0.66 \\
\hline Rio Grande do Sul & 0.044 & 0.044 & 0 & 0.04 & 0.97 \\
\hline Santa Catarina & 0.031 & 0.032 & -0.3 & -0.31 & 0.75 \\
\hline Sergipe & 0.002 & 0.002 & -0.1 & -0.09 & 0.93 \\
\hline Sao Paulo & 0.233 & 0.236 & -0.6 & -0.48 & 0.63 \\
\hline Tocantins & 0.006 & 0.005 & 0.1 & 0.12 & 0.90 \\
\hline
\end{tabular}

Source: own calculations.

\section{B. Results}

Our sample is composed of 72,781 individuals between the ages of 18 and 65 in 2007, whose household became eligible for Bolsa Familia due to the change in the eligibility criterion. This paper focuses on two outcome variables: sporadic formal labor market participation (whether an individual has appeared at least once in the RAIS over a certain number of years - formal at least once) and continuous formal labor market participation (whether an individual has appeared in the RAIS every month throughout a certain number of years - formal throughout). This paper considers two time periods, 2007-2011 and 2009-2011. On average, a higher percentage of individuals from beneficiary households transitioned into the RAIS at least once between 2007 and 2011 than those who were not beneficiaries, and a higher share had remained in the formal labor market throughout the period (Figure 3). 
Figure 3: Labor market formalization of Bolsa Familia beneficiaries and Non Bolsa Familia beneficiaries $(\%)$

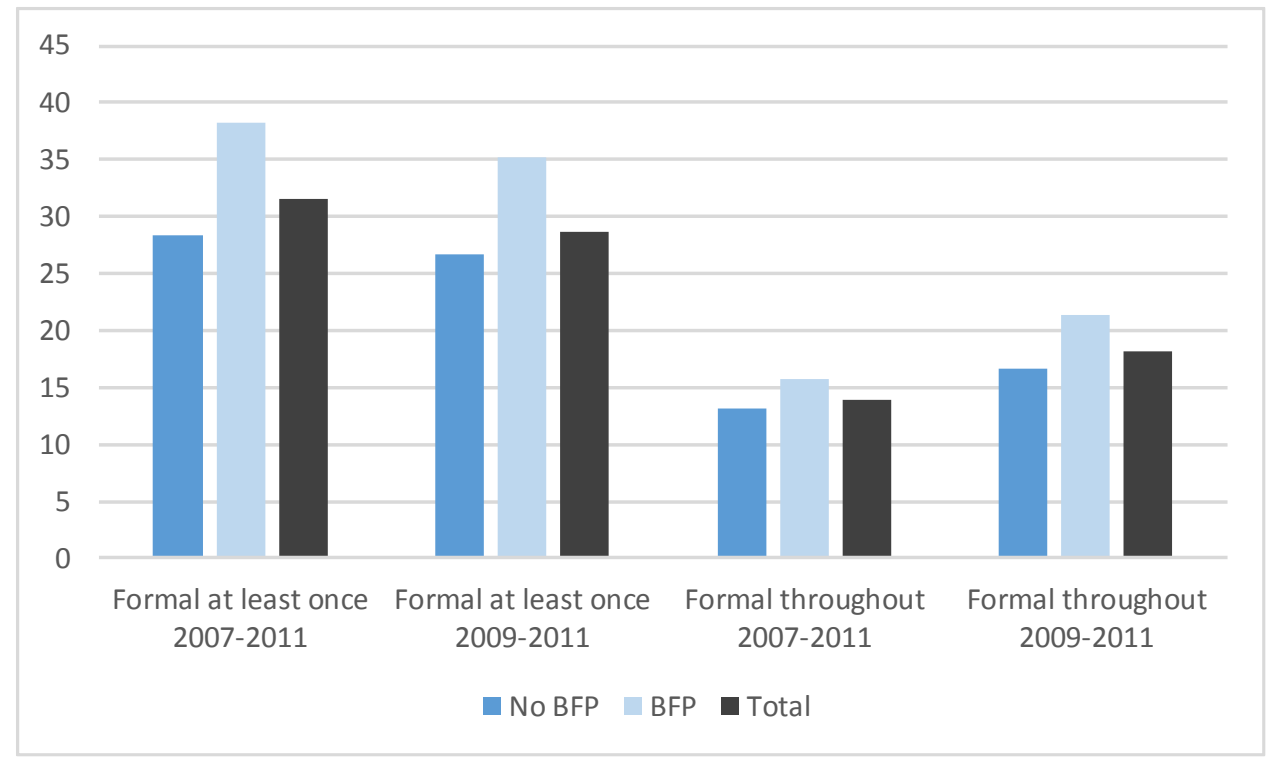

This paper estimates the probability of being formal in 2010 and 2011 for the whole sample of those who became eligible after the change in eligibility criteria, as well as for men and women separately. Our findings show that participation in Bolsa Familia had a positive and significant effect for both men and women (Table 6). Attachment to the formal labor market was limited (the share that appeared in the RAIS throughout the period was substantially smaller, especially for women), meaning that individuals were transitioning in and out of or having short spells in formal employment.

Table 6: Probability of being formal for all sample and by gender

\begin{tabular}{|c|c|c|c|c|}
\hline & Probability of being: & No BFP & BFP & $\Delta$ LATE \\
\hline \multirow{2}{*}{ All } & Formal at least once in 2010 or 2011 & 0.29 & 0.33 & $\begin{array}{c}\mathbf{0 . 0 4 7} \\
(0.004)\end{array}$ \\
\hline & Formal consecutively between 2010 and 2011 & 0.22 & 0.25 & $\begin{array}{r}\mathbf{0 . 0 3 3} \\
(0.004) \\
\end{array}$ \\
\hline \multirow{2}{*}{ Women } & Formal at least once in 2010 or 2011 & 0.204 & 0.251 & $\begin{array}{c}\mathbf{0 . 0 4 6} \\
(0.005)\end{array}$ \\
\hline & Formal consecutively between 2010 and 2011 & 0.145 & 0.171 & $\begin{array}{c}\mathbf{0 . 0 2 6} \\
(0.004) \\
\end{array}$ \\
\hline \multirow{2}{*}{ Men } & Formal at least once in 2010 or 2011 & 0.423 & 0.462 & $\begin{array}{r}\mathbf{0 . 0 3 9} \\
(0.006)\end{array}$ \\
\hline & Formal consecutively between 2010 and 2011 & 0.343 & 0.382 & $\begin{array}{c}\mathbf{0 . 0 4 0} \\
(0.006)\end{array}$ \\
\hline
\end{tabular}

Note: Computing average treatment effect on the treated. Standard Errors in parentheses. Standard errors are clustered at the municipal level.

Sources: own calculations, based on the Single Registry for Social Programs - December 2008, the Historical

Database of Benefits (2007-2009) and RAIS (2010-2011). 
When looking at the differential impact by age, this paper finds that the impact of Bolsa Familia is positive for the youngest age groups between 18 and 45 but strongest for the 25 to 35 age group (Table 7). The probability of being formal at least once in 2010 and 2011 for beneficiaries is 6.4 percentage points higher for beneficiaries than non-beneficiaries. The probability of being formal consecutively over this period is 4.8 percentage points higher for this age group. Bolsa Familia has a positive and significant impact on 18 to 25 and 35 to 45 year old, though for the latter the impact is the smallest (3.7 and 2.5 percentage points). There is no impact of the program on individuals between 45 and 65-year-old.

Table 7: Probabilities of being formal by age group

\begin{tabular}{|c|c|c|c|c|}
\hline Age & Probability of being: & No BFP & BFP & $\Delta$ LATE \\
\hline \multirow{2}{*}{18,25} & Formal at least once in 2010 or 2011 & 0.318 & 0.366 & $\begin{array}{c}\mathbf{0 . 0 4 8} \\
(0.010)\end{array}$ \\
\hline & Formal consecutively between 2010 and 2011 & 0.227 & 0.256 & $\begin{array}{r}\mathbf{0 . 0 3 0} \\
(0.009) \\
\end{array}$ \\
\hline \multirow{2}{*}{25,35} & Formal at least once in 2010 or 2011 & 0.305 & 0.369 & $\begin{array}{c}\mathbf{0 . 0 6 4} \\
(0.007)\end{array}$ \\
\hline & Formal consecutively between 2010 and 2011 & 0.234 & 0.281 & $\begin{array}{r}\mathbf{0 . 0 4 7} \\
(0.007) \\
\end{array}$ \\
\hline \multirow{2}{*}{35,45} & Formal at least once in 2010 or 2011 & 0.287 & 0.325 & $\begin{array}{c}\mathbf{0 . 0 3 7} \\
(0.007)\end{array}$ \\
\hline & Formal consecutively between 2010 and 2011 & 0.231 & 0.256 & $\begin{array}{c}\mathbf{0 . 0 2 5} \\
(0.006) \\
\end{array}$ \\
\hline \multirow{2}{*}{45,55} & Formal at least once in 2010 or 2011 & 0.204 & 0.213 & $\begin{array}{c}0.009 \\
(0.010)\end{array}$ \\
\hline & Formal consecutively between 2010 and 2011 & 0.163 & 0.169 & $\begin{array}{c}0.006 \\
(0.009)\end{array}$ \\
\hline \multirow[b]{2}{*}[55,65]{} & Formal at least once in 2010 or 2011 & 0.090 & 0.101 & 0.011 \\
\hline & Formal consecutively between 2010 and 2011 & 0.072 & 0.070 & $\begin{array}{c}(0.013) \\
-0.002 \\
(0.011)\end{array}$ \\
\hline
\end{tabular}

Note: Computing average treatment effect on the treated. Standard Errors in parentheses.

This paper is restricting to households who entered BF between change in eligibility rule and 2009, looking at their presence in RAIS in 2010 and 2011.

Sources: own calculations, based on the Single Registry for Social Programs - December 2008, the Historical Database of Benefits (2007-2009) and RAIS (2010-2011).

The lack of an effect on older generations is not surprising. Individuals in these age groups are likely to have spent most of their labor market trajectories in the informal sector. Prior evidence in the Brazilian labor market highlights that "a spell in an informal job acts as a 'scar' for the workers who experience it, signaling some characteristics that are not valued by formal employers" (Soares, 2004). Consequently, a late transition to the formal sector is considerably harder.

To understand the more surprising positive effect on formal employment for the younger generations it is helpful to think that some of the simplest models that predict negative effects on labor supply and on formal employment either do not take into account the costs of searching for a job or assume complete markets, where the costs of job searching could be 
easily covered by credit. The positive impact of cash transfers on the transition into the formal labor market can be more easily understood within this framework.

A complementary hypothesis is the presence of an indirect effect of the impact of cash transfers on psychological well-being. There is an increasing literature suggesting that scarcity can generate poor cognitive processing and decision-making, which, in turn, perpetuates poverty (Mullainathan and Shafir 2013). Some "slack" would be necessary to avoid depleting scarce cognitive resources and improve long-term decisions. In this vein, Attah et al. (2016) found that, in the context of four African countries, cash transfers were related to improvements in psychological well-being and, consequently, in educational performance, participation in social life and decision-making. Better labor market decisions (resulting in the enhanced probability of finding a formal job) might also be an indirect effect of improved psychological well-being, promoted by cash transfers.

\section{Robustness check}

As a robustness check for our results, this paper estimates the impact of the Bolsa Familia using difference in difference (DID) estimator. This paper takes all the households that became eligible to join the program after the change in the cutoff. Since this paper has panel data at the individual level over time, this paper compares the changes in outcomes over time between the households who became beneficiaries and those who did not. This approach removes biases in post-intervention period comparisons between the treatment and control group that could be the result from permanent differences between those groups, as well as biases that could be the result of trends due to other causes of the outcome.

The simplest DID estimator is:

$$
D I D=\left(Y_{t_{1}}^{T}-Y_{t_{0}}^{T}\right)-\left(Y_{t_{1}}^{C}-Y_{t_{0}}^{C}\right)
$$

Where $Y_{t_{1}}^{T}$ indicates formal labor market participation for Bolsa Familia participants after the change in eligibility criteria, while $Y_{t_{0}}^{T}$ formal labor market participation before the change, and $Y_{t_{1}}^{C}$ and $Y_{t_{0}}^{C}$ the analogous outcomes for non-beneficiaries. Table 8 shows the DID estimator for formal at least once in 2010 and 2011. As this paper can see, there is always a positive difference, that is the change in the share of individuals that have a formal job is higher for beneficiaries of Bolsa Familia than for non-beneficiaries. The difference increases between 2010 and 2011 (from 2.4 pp to 2.8 pp).

Table 8: Simple DID estimator

\begin{tabular}{|c|c|c|c|c|c|c|c|}
\hline & No BFP & BFP & $\Delta$ & & No BFP & BFP & $\Delta$ \\
\hline 2007 & 0.200 & 0.226 & $0.026^{* * * *}$ & 2007 & 0.200 & 0.226 & $0.026^{* * * *}$ \\
\hline 2010 & 0.233 & 0.283 & $0.050^{* * * *}$ & 2011 & 0.239 & 0.293 & $0.054^{* * * *}$ \\
\hline$\Delta$ & 0.033 & 0.057 & $0.024^{* * * *}$ & $\Delta$ & 0.039 & 0.067 & $\mathbf{0 . 0 2 8}^{* * * * *}$ \\
\hline
\end{tabular}

Sources: own calculations, based on the Single Registry for Social Programs - December 2008, the Historical Database of Benefits and RAIS (several years). 
To account for potential differences in observable characteristics between the control and the treatment group, this paper also computed the DID estimator combined with PSM. Using the same observable variable used previously and describe in Table 8 , this paper obtains estimates that are smaller, but still positive and significant (Table 9). While participation in formal labor market increased for both beneficiaries and non-beneficiaries of Bolsa Familia, the latter experienced a higher growth of 1.7 percentage points in 2010 and 1.9 in 2011.

Table 9: DID estimator using propensity score matching

\begin{tabular}{|c|c|c|c|c|c|c|c|}
\hline & No BFP & BFP & $\Delta$ & & No BFP & BFP & $\Delta$ \\
\hline 2007 & 0.223 & 0.226 & 0.003 & 2007 & 0.223 & 0.226 & 0.003 \\
\hline 2010 & 0.263 & 0.283 & $0.020^{* * * *}$ & 2011 & 0.271 & 0.293 & $0.022^{* * *}$ \\
\hline$\Delta$ & 0.040 & 0.057 & $0.017^{* * * *}$ & $\Delta$ & 0.048 & 0.067 & $0.019^{* * * *}$ \\
\hline
\end{tabular}

Sources: own calculations, based on the Single Registry for Social Programs - December 2008, the Historical Database of Benefits and RAIS (several years).

\section{Conclusions}

Simple theoretical models suggest that social benefits could have a negative impact on labor supply. Receiving benefits would produce an income effect, lessening the need for work. This effect could be amplified by high marginal tax rates. However, modest cash transfers were extensively studied and there is growing consensus that they do not have significant negative effects on labor supply.

When means tested, however, cash transfers could provide a disincentive to work in the formal labor market, especially in countries where the informal sector is large. Indeed, with means testing, poor families could lose their benefits if their income surpasses a certain threshold. As income from the informal sector is virtually undetectable by authorities, members of poor families might prefer working in the informal sector so that their families might keep their benefits. So far, this theoretical expectation has received mixed evidence from a relatively meager empirical literature.

In this paper, this paper has investigated the relationship between participation in a cash transfer program and participation in the formal labor market in Brazil. In our empirical analysis, this paper has linked the Single Registry for Social Programs (a comprehensive administrative record of poor and vulnerable households), the Bolsa Familia program's Historical Database of Benefits and RAIS, the registry of all formal workers, to document the patterns of formal labor market and program participation. To identify causal impact, this paper took advantage of a change in eligibility rule and the use of municipal quotas that affect participation in the program independently of observable characteristics of individuals or households.

Our findings have bearing on the long-standing debate over whether safety nets programs can have detrimental effect on the quality of jobs chosen by individuals. This paper estimates a positive effect of the program on formal labor market participation, especially for younger cohorts. The estimated average treatment effects on the treated (ATT) suggest that beneficiaries are 4.7 percentage points more likely to be found at least once in a formal job in 2010 or 2011 and 3.3 percentage points more likely to be found in a formal job throughout 
these two years, compared with the control group. Results are statistically significant for the whole sample, as well as for men and women separately and for the younger age groups (2535 and 35-45 years old). Robustness checks were performed using a difference-in-differences approach (DID). DID estimates, combined or not with PSM, were also positive and significant: beneficiaries are more likely to be found in the formal labor market than non-beneficiaries.

This paper argues that our results are consistent with the hypotheses that benefits can be used to meet the costs of job searching and can be indirectly associated with better long-term decisions in the labor market. 


\section{REFERENCES}

Attah, Ramlatu, Valentina Barca, Andrew Kardan, Ian Macauslan, Fred Merttens and Luca Pellerano. Can social protection affect psychosocial wellbeing and why does this matter? Lessons from cash transfers in Sub Saharan Africa. The Journal of Development Studies 52(8), 2016.

Baird, Sarah, David McKenzie and Berk Özler. The effects of cash transfers on adult labor market outcomes. IZA Journal of Development and Migration Vol. 8 No. 1, 2018.

Banerjee, Abhijit, Rema Hanna, Gabriel Kreindler and Benjamin A. Olken. Debunking the Stereotype of the Lazy Welfare Recipient: Evidence from Cash Transfer Programs Worldwide. World Bank Research Observer, Vol.32, Issue 2, August 2017.

Barbosa, Ana L. H. and Corseuil, Carlos H. Bolsa Família, escolha ocupacional e informalidade no Brasil. Texto para Discussão No. 1948. Rio de Janeiro: IPEA, 2014.

Barham, Tania, Karen Macours, and John A. Maluccio. Are conditional cash transfers fulfilling their promise? Schooling, learning, and earnings after 10 years. Mimeo, 2017.

Barros, Ricardo P., Mirela de Carvalho, Samuel Franco and Rosane Mendonça. A focalização do Programa Bolsa Família em perspectiva comparada. In: Lucia Modesto \& Jorge Castro (eds). Bolsa Família 2003-2010: avanços e desafios. Brasília: Ipea, 2010.

Barros, Ricardo P., Samuel Franco and Rosane Mendonça. Discriminação e segmentação no mercado de trabalho e desigualdade de renda no Brasil. Texto para Discussão No. 1288. Rio de Janeiro: IPEA, 2007.

Borjas, G. J. Labor Economics. New York: McGraw-Hill/Irwin, 2005.

Bastagli, F., J. Hagen-Zanker, L. Harman, V. Barca, G. Sturge, T. Schimidt and L. Pellerano. Cash Transfers: what does the evidence say? A rigorous review of Programme impact and of the role of design and implementation features. London: Overseas Development Institute (ODI), 2016.

Camacho, A., and E. Conover. Manipulation of social program eligibility. American Economic Journal: Economic Policy Vol. 3 No. 2, 2011.

Camargo, Camila F., Claudia Curralero, Elaine Lício and Joana Mostafa. Perfil socioeconômico dos beneficiários do Programa Bolsa Família: o que o Cadastro Único revela? In: T. Campello \& M. Nery. Programa Bolsa Família - Uma década de inclusão e cidadania. Brasília: IPEA, 2013.

De Brauw, Alan, Daniel Gilligan, John Hoddinott and Shalini Roy. Bolsa Familia and household labor supply. Economic Development and Cultural Change Vol. 63, n 3, 2015. 
Duncan, Greg J., Kathleen M. Harris and Johanne Boisjoly. Time Limits and Welfare Reform: New Estimates of the Number and Characteristics of Affected Families. Social Service Review, Vol. 74, No. 1, 2000.

Firpo, Sergio, R. Pieria, E. Pedroso Jr. \& A. P. Souza. Evidence of eligibility manipulation for conditional cash transfer programs. EconomiA, Vol. 15, No. 3, 2014.

Hellmann, Aline Gazola. "How does Bolsa Familia Work? Best practices in the Implementation of Conditional Cash Transfers Programs in Latin America and the Caribbean". Social Protection and Health Division, IDB, Technical Note n. IDB-TN-856, 2015

Kabeer, Naila, and Hugh Waddington. Economic impacts of conditional cash transfer programmes: a systematic review and meta-analysis. Journal of Development Effectiveness, Vol. 7, No. 3, 2015.

Kanbur, Ravi, Michael Keen and Matti Tuomala. Labor Supply and Targeting in Poverty Alleviation Programs. The World Bank Economic Review Vol. 8, n 2, 1994.

Lentz, Erin C., Christopher B. Barrett and John Hoddinott. Food Aid and Dependency: Implications for Emergency Food Security Assessments. World Food Programme, Emergency Needs Assessment Branch (ODAN). December 2005.

Moffitt, R. A. Welfare programs and labor supply. In: A. J. Auerbach and M. Feldstein (org.). Handbook of Public Economics, Vol. 4. North Holland: Elsevier, 2002.

Mullainathan, Sendhil and Shafir, Eldar. Scarcity: why having too little means too much. New York: Henry Holt, 2013.

Oliveira, Luis F. B. and Sergei O. S. Soares. O que se sabe sobre os efeitos das transferências de renda sobre a oferta de trabalho. Texto para Discussão n $^{\circ}$ 1738. Brasília: IPEA, 2012.

Santos, D. B., Alexandre R. Leichsenring, Naércio Menezes-Filho and Wesley M. da Silva. Os Efeitos do Programa Bolsa Família sobre a Duração do Emprego Formal das Pessoas Pobres. Conference Paper, XL Encontro da Associação Nacional dos Programas de Pós-Graduação e Pesquisa em Administração, September 2016

Silva, Joana, Flavio Cireno \& Rafael Proença. Improving Learning Outcomes Through Social Assistance: Regression-Discontinuity Evidence from Brazil. Mimeo, 2016.

Soares, Fabio V. Do informal workers queue for formal jobs in Brazil? Texto para Discussão n 1021. Brasília: IPEA, 2004.

World Bank. Closing the gap: The State of Social Safety Nets 2017. World Bank Group, 2017. 